\title{
ERRORS MADE BY THE EIGHTH GRADE STUDENTS OF SMP NEGERI 31 MEDAN IN WRITING ENGLISH COMPOSITIONS
}

\author{
Idam Putriyani Waruwu, Novalina Sembiring, Jontra Jusat Pangaribuan \\ Catholic University of Saint Thomas \\ Email:jontra_pangaribuan@ust.ac.id
}

\begin{abstract}
Writing English composition is more complicated than Indonesian compositions. Therefore, students often make errors in writing English compositions. This study aims at finding out the errors made by the eighth grade students of SMP Negeri 31 Medan in writing English composition and to find out the causes of those errors. The population of this study is the eighth grade students of SMP Negeri 31 Medan in Academic Year 2017/2018. The sample is class VIII-A with 30 students. The instrument for collecting data were the students' English compositions and the questionnaires. The result from the students' English compositions showed that third singular verb in morphological errors is the highest error made by the students $(55,10 \%)$, followed by errors in definite article $(20,40 \%)$, errors in Possesive Case $(12,24 \%)$, errors in Comparative Adjective or Adverb (12,24\%); the errors of syntactical errors in Verb or Verb Phrase (50\%), Errors in Noun or Noun Phrase $(25 \%)$ and Errors in Word order (25\%). It means that the eighth grade students of SMP Negeri 31 Medan are poor in writing English compositions. While the result of the questionnaires showed that there are several reasons that cause students error. The three highest reasons are the students do not have a sufficcient vocabulary, students do not comprehend how to use the third singular verbs, article and possesive and the English teacher never asked the students to write English compositions. Thus, the students are suggested to study and more about writing English compositions and to do exercises about it. The teacher should give more writing practice to the students.
\end{abstract}

\section{Keywords: Errors, writing, English compositions}

\section{Introduction}

English is a foreign language learned at schools in Indonesia. Richard (1974:1) states that learning a second or foreign language can not be separated from creating errors. Errors made by the learners occur in many ways even when they listen, speak, read and write. Therefore, errors are something natural in learning a foreign language.

There are several factors which can cause the students to make the errors. Richard (1974:174) states that errors are not only caused by the interference from the mother tongue, but also what he calls overgeneralization the rules restriction, incomplete application of rules, and false concepts hypothesized. The objectives of this study are to find out the errors made by the eighth grade students of SMP NEGERI 31 MEDAN in writingEnglish compositions and find out the reasons of the students make errors in writing English compositions in such a way.

Writing is a communication process between the writer and the reader in a written form. Troyka (1987:3) states that writing is a way of communicating a 
message to a reader for purposes. Harmer (2004:1) states that writing involves the encoding of a message of some kind: that is, we translate our thoughts into a language. Writing gives the readers an opportunity to think and express idea and some information for the readers; it also makes good connection among our ideas in indirect form. According to Heffernan and Lincoln (1986:4), through writing, we have time to think, to try out ideas on pieces of paper, to find what the writer means . Sinclair (1987:285) states that composition is a piece of written work, especially one that you write at school to show your skill and imagination.

Writing composition is a task, which involves the manipulating of words in correct sentences to form a piece of good writing that successfully communicates the writer's intention on a specific topic. Integrating new ideas in a composition needs special skills writing should be arranged in a good construction.

Byrne (1979:3-4) states that writing is commonly a difficult activity for most people, both in mother tongue and in a foreign language. The difficulties are caused by several problems such as psychological, linguistic and cognitive problem.

\section{Psychological Problems}

Writing is essentially a solitary activity and the fact that we are required to write on our own. In this case, the writer tries to tell something to the readers. Without the possibility of interaction or the benefit of feedback from the readers, the writer will feel difficult in writing. The feedback from the readers will influence the writers' mind and behavior.

\section{Linguistic Problems}

In writing, we have to compensate for the absence of some features. We have to keep the channel of communication open through our own efforts and to ensure, both through our choice of sentence structure and by the way our sentences are linked together and sequenced, that the text we produce can be interpreted on its own. We have to pay attention to the particular language that we use in writing.

\section{Cognitive Problems}

Writing is learnt through a process of instruction. We have to master written form of the language and to learn certain structures which are less used in speech, or perhaps not used at all, but which are important for effective communication in writing. We also have to learn how to organise our ideas in such a way that they can be understood by a reader who is not present and perhaps by a reader who is not known to us.

Writing has some purposes. Farmer (1982:315) describes some purposes of writing, they are to clarify a thought, a feeling, an impression, or an experience for a reader, to provide information for the readers, to persuade the readers to accept an idea and to create a piece of imaginative literature that a reader might enjoy.

According to Gerot and Wignell (1994:195-208), there are some types of writing, they are recount, report, analytical exposition, news item, anecdote, narrative, procedure and descriptive text.

In order to understand what an error is in the process of learning, there are some defenitions of error which are proposed by some linguists. Dulay et al., (1982:138) state that an error is the flawed side of leaners' speech of writing. They are parts of conversation or composition that deviate from some selected norms of nature language performance. 
Furthermore, Corder (1979:122) uses the term errorneous to refer to error, he describes an error as either superficially deviant or inappropriate terms of the target language grammar as the usual practice. In learning a language, making errors cannot be avoided. A learner cannot learn a language without making errors. The errors are used as feedback in teaching-learning processes.

Based on the explanation, the writer concludes that learners make an error if their written expression grammaticaly deviate form the syntatic rules of the target language.

\section{Errors versus Mistakes}

In connection with errors in language teaching, errors, as Norrish (1983:78) notes, are caused by the learners on the processing the knowledge in the second language rule systems. As a consequence, they are not ready to correct their errors. This limited competence is caused by their knowledge that is still developing.

Dulay et al., ( 1982:146-192) propose four basic classification of errors. There are classification of error based on linguistic category taxonomy, classification based on surface strategy taxonomy and classification based on comparative taxonomy.

There are some experts who are stated the factor causing the errors. According to Brown (1980:173-174), there are three basic factors of a learner's producing errors in learning a new language. These factors consist of interlingual transfer, intralingual transfer, and context of learning.

\section{Methodology}

This study used qualitative and quantitative research method. Anderson and Arsenault (2005:126) state that qualitative research is an inductive form of inquiry whose results are a blend of research skill, luck, case study and a particular perspective.

Quantitative data are data that deal with quantities, values or numbers, making them measurable. According to Cramer (2003:2), data is quantitative in the sense that the frequency, proportion or percentage of cases can be quantified.

The data of this study were gathered through students' writing composition product. The writer collected the students' writing composition and then read those texts carefully. After that, the writer distributed questionnaire to the students in order to gain information about the students' reasons of making the errors.

\section{Instruments of Collecting Data}

To conduct this study, the writer used two kinds of instruments. The first instrument was the students' writing composition. The second instrument was the quetionnaire. The writer distributed questionnaires to the students to know their difficulties and the cause of the errors.

\section{Technique of Data Analysis}

The technique that the writer used to analyze the data is descriptive analysis technique with the percentage from the frequency of information and 
divided with some number of errors. The numbers of the errors were calculated in a formula as follows:

$M=\frac{\sum \mathrm{X}}{N} \times 100 \%$

Notes:

$\mathrm{M}=$ the mean of students' error

$\sum \mathrm{X}=$ the total number of each error

$\mathrm{N}=$ the total number of all errors

Below is the example of how to calculate the percentage of each item of errors:

The sum of error in definite article:

$\mathrm{X}$ definite article:

$$
\begin{aligned}
M & =\frac{14}{54} \times 100 \% \\
& =25,92 \%
\end{aligned}
$$

\section{The Data Analysis}

The percentage of the students' errors was calculated from each word and sentence in their writing composition. The formula of analyzing the percentage of students' error is shown as follows:

$$
M=\frac{\sum \mathrm{X}}{N} \times 100 \%
$$

Where: $\mathrm{M}=$ the mean of students' error

$\sum X=$ the total number of each error

$\mathrm{N}=$ the total number of all errors

Table 1 The Types of Students' Errors in Morphological

\begin{tabular}{|c|l|c|c|}
\hline No & Category of Error & Number of Errors & Percentage \\
\hline 1 & Definite Article & 10 & $20.40 \%$ \\
\hline 2 & Possessive Case & 6 & $12.24 \%$ \\
\hline 3 & Third Singular Verb & 27 & $55.10 \%$ \\
\hline 4 & $\begin{array}{l}\text { Comparative Adjective or } \\
\text { Adverb }\end{array}$ & 6 & $12.24 \%$ \\
\hline 5. & Regular or Irregular Verb & 0 & $0 \%$ \\
\hline
\end{tabular}

Based on the table, the number of errors made by the students in definite article is $10(20.40 \%)$ errors, the number of students' error in possessive case is 6 $(12.24 \%)$, the number of students' error in third singular verb is $27(55.10 \%)$, the number of students' error in comparative adjective or adverb is $6(12.24 \%)$, and the number of students' error in regular or irregular verb is $0(0 \%)$.

Table 2 The Descriptions of Students' Errors in Morphological 
KAIROS ELT JOURNAL, Vol. 3 No. 1 April 2019

Copyright@2019, ISSN: 2580-4278

\begin{tabular}{|c|c|c|}
\hline No. & Error & Correction \\
\hline \multicolumn{3}{|c|}{ Definite Article } \\
\hline 1. & A short hair & Short hair \\
\hline 2. & He is president no.7 Indonesia. & $\begin{array}{l}\mathrm{He} \text { is the seventh } \\
\text { president of Indonesia. }\end{array}$ \\
\hline 3. & He is aactor. & He is an actor. \\
\hline 4. & He is actor famous international. & $\begin{array}{l}\mathrm{He} \text { is the famous } \\
\text { international actor. }\end{array}$ \\
\hline 5. & Mr. Jokowi like shirt party. & $\begin{array}{l}\text { Mr. Jokowi likes to wear } \\
\text { shirt party. }\end{array}$ \\
\hline 6. & Mr. Jokowi is president of Indonesia. & $\begin{array}{l}\text { Mr. Jokowi is the } \\
\text { president of Indonesia. }\end{array}$ \\
\hline \multicolumn{3}{|c|}{ Possessive Case } \\
\hline 7. & $\underline{\text { She body }}$ & Her body \\
\hline 8. & His my friend & His friend \\
\hline 9. & She character & Her character \\
\hline 10. & Justin Bieber hair is brown. & $\begin{array}{l}\text { Justin Bieber's hair is } \\
\text { brown. }\end{array}$ \\
\hline \multicolumn{3}{|c|}{ Third Singular Verb } \\
\hline 11. & She have & She has \\
\hline 12. & He have & He has \\
\hline 13. & He live in Indonesia. & He lives in Indonesia. \\
\hline 14. & Mr. Jokowilike shirt party. & $\begin{array}{l}\text { Mr. Jokowi likes the shirt } \\
\text { party. }\end{array}$ \\
\hline 15. & Reza have long hair. & Reza has long hair. \\
\hline \multicolumn{3}{|c|}{ Comparative Adjective or Adverb } \\
\hline 16. & Mr. Jokowi is tall than my father. & $\begin{array}{l}\text { Mr. Jokowi is taller than } \\
\text { my father. }\end{array}$ \\
\hline 17. & Mr. Jokowi is the smart president. & $\begin{array}{l}\text { Mr. Jokowi is the } \\
\text { smartest president. }\end{array}$ \\
\hline 18. & Chelsea Olivia is old than me. & $\begin{array}{l}\text { Chelsea Olivia is older } \\
\text { than me. }\end{array}$ \\
\hline 19. & Agnes Monica is good than Dewi Persik. & $\begin{array}{l}\text { Agnes Monica is better } \\
\text { than Dewi Persik. }\end{array}$ \\
\hline 20 . & Chelsea Olivia is beautiful so much now. & $\begin{array}{l}\text { Chelsea Olivia is more } \\
\text { beautiful now. }\end{array}$ \\
\hline 21. & Prilly is the cute artist. & Prilly is the cutest artist. \\
\hline
\end{tabular}

The analysis of syntactical errors was presented as follow:

Table 3 The Types of Students' Errors in Syntactical

\begin{tabular}{|c|c|c|c|}
\hline No & Category of Errors & Number of Errors & Percentage \\
\hline
\end{tabular}




\begin{tabular}{|c|l|c|c|}
\hline 1 & Noun or Noun Phrase & 9 & $25 \%$ \\
\hline 2 & Verb or Verb Phrase & 18 & $50 \%$ \\
\hline 3 & Word Order & 9 & $25 \%$ \\
\hline
\end{tabular}

Based on the table, the number of students' error in noun or noun phrase is $9(25 \%)$ errors, the number of students' error in verb or verb phrase is $18(50 \%)$ errors and the number of students' error in word order is $9(25 \%)$ errors.

Table 4 The Descriptions of Students' Error in Syntactical

\begin{tabular}{|c|c|c|}
\hline No. & Error & Correction \\
\hline \multicolumn{3}{|c|}{ Noun or Noun Phrase } \\
\hline 1. & He is president no.7 Indonesia. & $\begin{array}{l}\mathrm{He} \text { is the seventh } \\
\text { president of Indonesia. }\end{array}$ \\
\hline 2. & He is 54 old. & He is 54 years old. \\
\hline 3. & Mr. Jokowi very handsome. She is good. & $\begin{array}{l}\text { MrJokowi is very } \\
\text { handsome. He is good. }\end{array}$ \\
\hline 4. & He is actor famous international. & $\begin{array}{l}\mathrm{He} \text { is the famous } \\
\text { international actor. }\end{array}$ \\
\hline 5. & Him diligent and well. & $\mathrm{He}$ is diligent and well. \\
\hline \multicolumn{3}{|c|}{ Verb or Verb Phrase } \\
\hline 5. & Favorite my Agnes Monica & $\begin{array}{l}\text { My favorite actress is } \\
\text { Agnes Monica. }\end{array}$ \\
\hline 6. & Reza very handsome. & Reza is very handsome. \\
\hline 7. & Mr. Jokowi age 54 years old. & $\begin{array}{l}\text { Mr. Jokowiis } 54 \text { years } \\
\text { old. }\end{array}$ \\
\hline 8. & Him diligent and well. & $\mathrm{He}$ is diligent and well. \\
\hline 9. & She very famous. & She is very famous. \\
\hline 10. & She no arrogant. & She is not arrogant. \\
\hline 11. & Mr. Jokowidon't fat. & Mr. Jokowïis not fat. \\
\hline 12. & He famous. & He is famous. \\
\hline 13. & Mr. Jokowi not like corruption. & $\begin{array}{l}\text { Mr. Jokowidoes not } \\
\text { likecorruption. }\end{array}$ \\
\hline \multicolumn{3}{|c|}{ Word Order } \\
\hline 14. & Actress favorite & Favorite actress \\
\hline 15. & Skin white & White Skin \\
\hline 16. & Favorite my actress & My favorite actress \\
\hline 17. & Favorite my Agnes Monica & $\begin{array}{l}\text { My favorite actress is } \\
\text { Agnes Monica. }\end{array}$ \\
\hline 18. & $\begin{array}{l}\text { If come Reza, I will to ask photo with } \\
\text { Reza. }\end{array}$ & $\begin{array}{l}\text { If Reza come, I would } \\
\text { like to take some photos } \\
\text { with him. }\end{array}$ \\
\hline
\end{tabular}




\begin{tabular}{|l|l|l|}
\hline 19. & He is the president of the no.7 Indonesia. & $\begin{array}{l}\text { He is the seventh } \\
\text { president of Indonesia. }\end{array}$ \\
\hline 20. & Beautiful is her face. & Her face is beautiful. \\
\hline 21. & He gives a example good for us. & $\begin{array}{l}\text { He gives a good example } \\
\text { for us. }\end{array}$ \\
\hline 22. & Nose sharp & Sharp nose \\
\hline
\end{tabular}

\section{The Analysis of the Students' Questionnaire}

The formula of questionnaire was:

$$
M=\frac{\sum \mathrm{X}}{N} \mathrm{x} 100 \%
$$

Where: $\mathrm{M}=$ the mean of students' questionnaire

$\sum \mathrm{X}=$ the total of students' choice (frequency)

$\mathrm{N}=$ the total number of students who were given the questionnaire

The three highest reasons of the students making errors in writing English compositions are: Students did not have a sufficient vocabulary to write English compositions (100\%), students do not comprehend how to use the third singular verbs, article and possessive in writing English compositions (96,6\%), and the English teacher never asked the students to write English composition text $(93,3 \%)$.

It could be seen that the highest frequency is in the cognitive problem $60 \%$, followed by psychological problem 30,98\% and linguistic problem 9,02\%.

The formula of analyzing the percentage ofthe problems is shown as follows:

$$
M=\frac{\sum \mathrm{X}}{N} \times 100 \%
$$

Where: $\mathrm{M}=$ the percentage ofthe problem

$\sum \mathrm{X}=$ the total number of each problem

$\mathrm{N}=$ the total number of all problem

Based on the result of data, the students made some errors in English writing composition text. There were:

In the students' error test, the results of students' error were divided into two types. First, in morphological errors, the percentage of students' error in definite article was $20.40 \%$, possessive case was $12.24 \%$, third singular verb was $55.10 \%$, and comparative adjectival or adverb was $12.24 \%$. Second, in syntactical errors, the percentage of students' error in noun or noun phrase was $25 \%$, verb or verb phrase was $50 \%$, and word order was $25 \%$.

Based on the students' questionnaire, there were several reasons that cause the students error based on psychological, linguistic, and cognitive. Most of the students had difficulty to write English composition text. The third highest reasons were students had difficulty to write English composition text because students did not have a sufficient vocabulary to write English compositions (100\%), students do not comprehend how to use the third singular verbs, article and possessive in 
writing English compositions (96,6\%), and the English teacher never asked the students to write English composition text $(93,3 \%)$.

\section{Conclusions and Suggestions \\ 4.1 Conclusions}

Based on the analysis and the description of data, the writer draws the following conclusions:

1. The errors made by the eighth grade students of SMP Negeri 31 Medan in writing English compositions are both in morphological and syntactical errors. In morphological, they made errors in the third singular verb, definite article, possesive case and comparative adjective or adverb. While in syntactical, they made errors in verb or verb phrase, noun or noun phrase and word order.

2. The reasons of the students made the errors were because the students did not have a sufficient vocabulary to write English compositions, students did not comprehend how to use the third singular verbs, article and possessive in writing English compositions.

3. The errors in the third singular verbs in morphological errors are the highest frequency of the types of errors.

\subsection{Suggestions}

Based on the conclusions, some suggestions are stated as follows:

1. The students

The students should memorize the grammatical forms, such as using third singular, tense, comparative, noun phrase, verb phrase, and word order in order to make a good English writing composition text. The students need to read their writing in order to find the errors by themselves, so that they can improve their English writing compositions.

2. The English teachers

The English teacher should be able to explain the rules of using sentence and paragraph in English writing composition text.

3. Other writers

The other writers are expected to investigate the students' errors and reasons that in another type of writing in order to see the development of students' English writing skill.

\section{BIBLIOGRAPHY}

Anderson, Gary and Arsenault, Nancy. 2005. Fundamental of Educational Research. London: Roudledge.

Ary, Donald., et al. 1979. Introduction to Research in Education. New York: Holt, Rinehart and Winston.

Broughton, Geoffrey., et al. 1978. Teaching English as A Foreign Language. London: Routledge and Regan Paul. 
Brown, H. Douglas. 1982. Principles of Language Learning and Teaching. Engliwood Cliffs: NJ. Prentice Hall.

Byrne, Donn. 1979. Teaching Writing Skills. Singapore: Longman Singapore Publisher.

Cooley, Thomas. 1992. The Norton Guide to Writing. London: Norton Company.

Corder, S. Pit. 1979. Techniques in Aplied Linguistics. Oxford: Oxford Univers ity Press.

Cramer, Duncan. 2003. Advanced Quantitative Data Analysis. New York: Open University Press.

Denman, A. Gregory. 2013. Think It, Show It Mathematics. Cambridge: Lesley University.

Dulay, Burt., et al. 1982. Language Two. New York: Institute D'Etudhes Theologiques.

Farmer, Marjorie. 1982. Composition and Grammar. San Fransisco: Laidlaw Brothers Pub.

Gerot, Linda and Wignell, P. 1994. Making Sense of Functional Grammar. Sydney: Gerd Stabler.

Harmer, Jeremy. 2004. How to Teach Writing. Harlow: Longman.

Heffernan, James and Lincoln, John. 1986. Writing a College Handbook. New York: W.W. Norton and Company.

Gubrium, Jaber and Holstein, James. 2002. Handbook of Interview Research. California: Thousand Oaks.

Jackson, Hoard and Stockwell, Peter. 2013. An Introduction to the Nature and Functions of Language. New York: Continuum International Publishing Group.

Marselyna, Dita. 2013. An Error Analysis in Writing Composition Made by the Second Grade Students of SMK Marsudi Luhur II Yogyakarta. An Unpublished Sarjana's Thesis, Faculty of Teachers Training and Education: Sanata Dharma University Yogyakarta.

Ningsih, Rachmawati. 2004. Error Analysis in the Students' English Writing. Unpublished Sarjana's Thesis, Faculty of Tarbiyah and Teachers Training: Syarif Hidayatullah State Islamic University Jakarta. 
KAIROS ELT JOURNAL, Vol. 3 No. 1 April 2019

Copyright@2019, ISSN: 2580-4278

Norrish, John. 1983. Language Learners and Their Errors. London: Longman Group.

Richard, Jack. 1974. Perspective on Second Language Acquisition. London: Longman.

Sinclair, John. 1987. Build English Language Dictionary. London: Collin Publisher.

Troyka, Lynn. 1987. Handbook for Writers. Englewood: Prentince Hall.

Wardhani, Dwi Taurina Milala. 2015. Error Analysis of Written English Compositions. Journal of Error Analysis of Written English Composition. $5(1)$.

Wilkinson, David and Birmingham, Peter. 2003. Using Research Instruments: A Guide for Researchers. New York: Psychology Press. 